\title{
Geodetic fault slip rates on active faults in the Baza sub-Basin (SE Spain): Insights for seismic hazard assessment
}

\author{
P. Alfaro ${ }^{\text {a }}$, A. Sánchez-Alzola ${ }^{\text {b }}$, I. Martin-Rojas ${ }^{\text {a, } \star}$, F.J. García-Tortosa ${ }^{\text {c,d }}$, J. Galindo-Zaldívar ${ }^{\text {e,f }}$, \\ M. Avilés ${ }^{\text {c,g,h }}$, A.C. López Garrido ${ }^{f}$, C. Sanz de Galdeano ${ }^{f}$, P. Ruano ${ }^{\text {e,f }}$, F.J. Martínez-Moreno ${ }^{i}$, \\ A. Pedrera ${ }^{j}$, M.C. Lacy ${ }^{\text {c, g,h }}$, M.J. Borque ${ }^{\text {c,g,h }}$, I. Medina-Cascales ${ }^{\text {a }}$, A.J. Gil ${ }^{\text {c, g,h }}$ \\ ${ }^{a}$ Departamento de Ciencias de la Tierra y del Medio Ambiente, Facultad de Ciencias, Universidad de Alicante, 03080, Alicante, Spain \\ ${ }^{\mathrm{b}}$ Departamento de Estadística e Investigación Operativa, Universidad de Cádiz, 11510, Puerto Real, Spain \\ c Centro de Estudios Avanzados en Ciencias de la Tierra, Energía y Medio Ambiente (CEACTEMA), Universidad de Jaén, Campus de las Lagunillas, 23071, Jaén, Spain \\ ${ }^{\mathrm{d}}$ Departamento de Geología, Facultad de Ciencias, Universidad de Jaén, 23071, Jaén, Spain

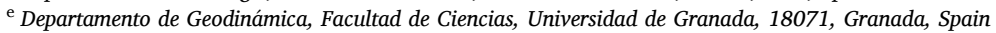 \\ ${ }^{\mathrm{f}}$ Instituto Andaluz de Ciencias de la Tierra (CSIC-Univ. de Granada), 18071, Granada, Spain \\ ${ }^{g}$ Grupo de Investigación RNM282-Microgeodesia Jaén, Universidad de Jaén, Campus Las Lagunillas s/n, 23071, Jaén, Spain \\ ${ }^{\mathrm{h}}$ Departamento de Ingeniería Cartográfica, Geodésica y Fotogrametría, Universidad de Jaén, Campus de las Lagunillas, 23071, Jaén, Spain \\ ${ }^{\mathrm{i}}$ Instituto Dom Luiz (IDL), Faculdade de Ciências, Universidade de Lisboa, Campo Grande, 1749-016, Lisboa, Portugal \\ ${ }^{\mathrm{j}}$ Instituto Geológico y Minero de España, Ríos Rosas, 23, 28760, Madrid, Spain
}

\section{A R T I C L E I N F O}

\section{Keywords:}

Active Tectonics

Betic Cordillera

Kinematic coherence

GPS

\begin{abstract}
A B S T R A C T
One of the most significant parameters for seismic hazard assessment analyses is the fault slip rate. The combination of both geological (long-term) and geodetic (short-term) data offers a more complete characterization of the seismic potential of active faults. Moreover, geodetic data are also a helpful tool for the analysis of geodynamic processes. In this work, we present the results of a local GPS network from the Baza sub-Basin (SE Spain). This network, which includes six sites, was established in 2008 and has been observed for seven years. For the first time, we obtain short-term slip rates for the two active faults in this area. For the normal Baza Fault, we estimate slip rates ranging between $0.3 \pm 0.3 \mathrm{~mm} / \mathrm{yr}$ and $1.3 \pm 0.4 \mathrm{~mm} / \mathrm{yr}$. For the strike-slip Galera Fault, we quantify the slip rate as $0.5 \pm 0.3 \mathrm{~mm} / \mathrm{yr}$. Our GPS study shows a discrepancy for the Baza Fault between the short-term slip rates and previously reported long-term rates. This discrepancy indicates that the fault could be presently in a period with a displacement rate higher than the mean of the magnitude 6 seismic cycle. Moreover, the velocity vectors that we obtained also show the regional tectonic significance of the Baza Fault, as this structure accommodates one-third of the regional extension of the Central Betic Cordillera.

Our GPS-related slip rates form the basis for future seismic hazard analysis in this area. Our results have further implications, as they indicate that the Baza and Galera Faults are kinematically coherent and they divide the Baza sub-Basin into two tectonic blocks. This points to a likely physical link between the Baza and Galera Faults; hence, a potential complex rupture involving both faults should be considered in future seismic hazard assessment studies.
\end{abstract}

\section{Introduction}

Fault slip rates are the principal controls on the tectonic activity and seismic potential of a region. This relation is the reason why slip rates are one of the most sensitive inputs for seismic hazard assessment models (Cornell, 1968; McGuire, 2007, among many others). In regions with low deformation rates, most seismic hazard assessments are based on geological evidence providing long-term fault slip rates (e.g., Faure Walker et al., 2010). These rates summarize multi-millennial records of cumulative earthquake displacements and cover multiple seismic cycles, yielding average recurrence intervals for individual faults. In recent years, this approach has been complemented with data from local GPS networks. These networks provide present deformation rates and, hence, short-term slip rates that are helpful to estimate the seismic potential of

\footnotetext{
* Corresponding author.

E-mail address: ivan.martin@ua.es (I. Martin-Rojas).
} 
active faults. Further analyses of local GPS networks are also an open window to geodynamical processes at the millimetric level (e.g., Larson et al., 2004; Smith et al., 2004; Kouba, 2005; Hreinsdóttir et al., 2006).

The Betic Cordillera (Fig. 1) is located in the western Mediterranean region, where the Nubian and Eurasian plates slowly converge. This active convergence is responsible for the development of more than one hundred active faults. Most of the quantitative deformation data related to these faults are geologically derived long-term slip rates (García-Mayordomo et al., 2012; Pedrera et al., 2012; Sanz de Galdeano et al., 2020). Geodetic short-term slip rates in the Betic Cordillera related to individual faults are scarce. The first geodetic data of slip rates were initially obtained from high-precision levelling profiles, providing vertical uplift rates for faults located in the Eastern Betic Cordillera (Giménez, 1998; Giménez et al., 2009). In the last two decades, several local GPS networks have been established in different areas: along the Carboneras and Alhama de Murcia Faults (Colomina et al., 1998; Echeverria et al., 2013, 2015), the Padul Fault (Gil et al., 2002 and 2017; Ruiz et al., 2003), the Bajo Segura and Crevillente Faults (Borque et al., 2019), the Zafarraya Fault (Galindo Zaldívar et al., 2003), the Balanegra Fault (Marin-Lechado et al., 2010; Galindo-Zaldivar et al., 2013), and the Baza and Galera Faults (this study). Until now, these local GPS networks have provided only a few short-term fault slip rates: $1.5 \pm 0.2$ $\mathrm{mm} / \mathrm{yr}$ for the Alhama de Murcia Fault (Echeverria et al., 2013), $1.3 \pm$ $0.2 \mathrm{~mm} / \mathrm{yr}$ for the Carboneras Fault (Echeverria et al., 2015), $\sim 0.9$ $\mathrm{mm} / \mathrm{yr}$ for the Padul Fault (Gil et al., 2017), $0.6 \pm 0.2 \mathrm{~mm} / \mathrm{yr}$ for the Bajo Segura Fault (Borque et al., 2019) and $0.7 \pm 0.2 \mathrm{~mm} / \mathrm{yr}$ for the Crevillente Fault (Borque et al., 2019).

In the present work, we provide new data from a local GPS network in the Baza sub-Basin (BsB), a key area located in the transition zone between two major tectonic domains of the Betic Cordillera. In this area, two active faults have been described, the Baza and Galera Faults (Alfaro et al., 2008; García Tortosa et al., 2011). Only long-term geological and geomorphological slip rates have been previously reported for these two active structures. Our geodetic data permit us to estimate the velocity field in the BsB, to interpret these velocities in terms of fault kinematics and to constrain the short-term fault slip rates. In addition, we compare our GPS-derived short-term slip rates with long-term geological rates to derive implications for seismic hazard assessment. We also propose a local tectonic model involving both faults that could be incorporated into future regional geodynamic interpretations and that has further implications for seismic hazard analyses.

\section{Regional geodynamic setting}

The western Mediterranean area (Fig. 1) is characterized by NNWSSE convergence of the Nubian and Eurasian plates, as mentioned above. The convergence rate is approximately $5-6 \mathrm{~mm} / \mathrm{yr}$ according to several regional geodetic studies (Nocquet and Calais, 2003; McClusky et al., 2003; Serpelloni et al., 2007; Stich et al., 2006, 2007; Pérez-Peña et al., 2010; Nocquet, 2012). This convergence is not uniformly distributed (Serpelloni et al., 2007; Pérez-Peña et al., 2010; Vernant et al., 2010; Koulali et al., 2011; Spakman et al., 2018, among others), as approximately two-thirds of the convergence is accommodated in the southern margin (North Africa) and only one-third is accommodated in the northern margin (Betic Cordillera and Algero-Balearic Basin).

Under this convergent setting, two major tectonic domains can be distinguished in the Betic Cordillera: i) the Eastern Betic Cordillera, dominated by active strike-slip tectonics (Bousquet, 1979; De Larouzière

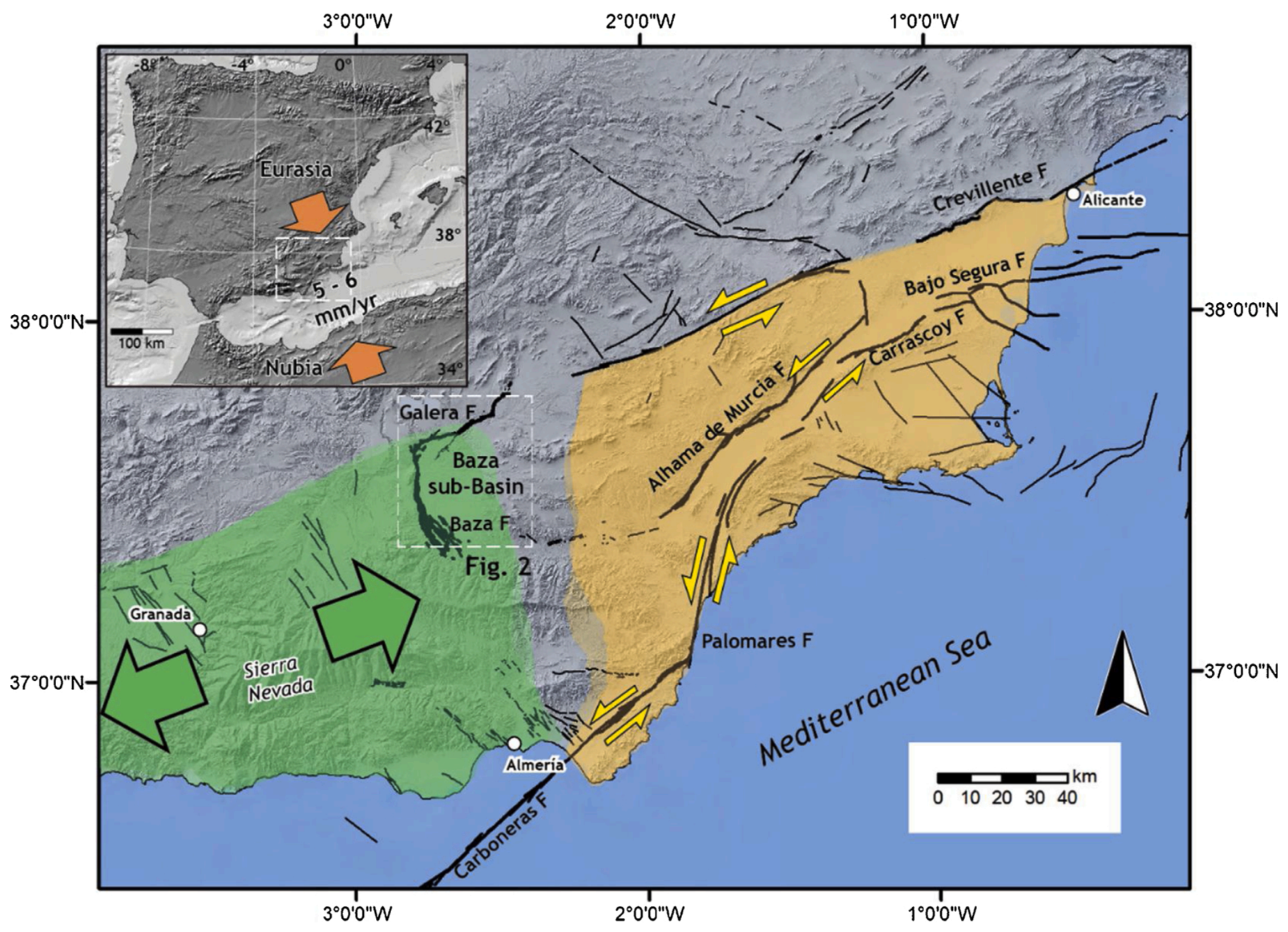

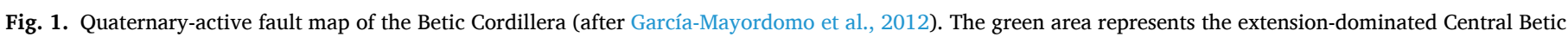

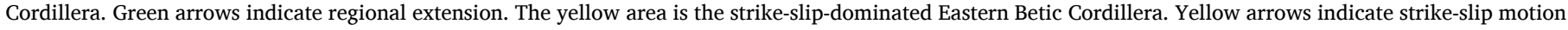
along the main active faults. Inset shows the regional convergence in the western Mediterranean between Nubia and Eurasia (orange arrows). 
et al., 1988; Silva et al., 1993), and ii) the Central Betic Cordillera, dominated by active NE-SW to ENE-WSW extension (Galindo-Zaldívar et al., 1993; Stich et al., 2006, 2007; Pérez-Peña et al., 2010). Our study area, the $\mathrm{BsB}$, is located in the transition zone between these two major tectonic domains (Figs. 1 and 2).
To the east of the BsB (Fig. 1), the Eastern Betic Cordillera is dominated by active strike-slip tectonics (Bousquet, 1979; De Larouzière et al., 1988; Silva et al., 1993), probably related to the presence of a thin and rigid crustal indenter in the Algero-Balearic Basin (Coppier et al., 1989; Palano et al., 2015; Borque et al., 2019). Active structures in the

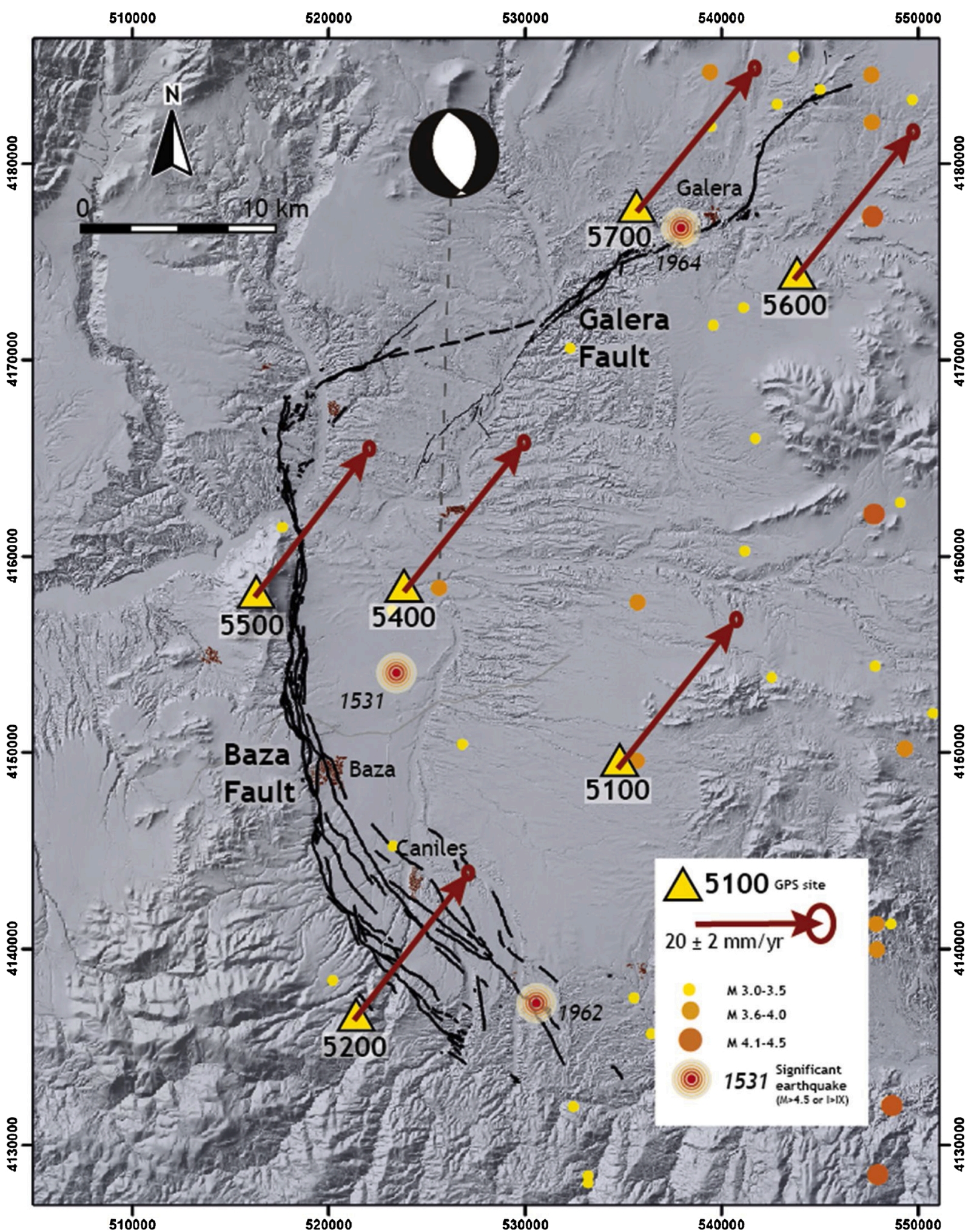

Fig. 2. Active faults in the BsB and the locations of sites in our local GPS network. Red arrows indicate the absolute velocity field derived from the position time series in the IGS08b reference frame and $95 \%$ confidence ellipses. The noise model for the data is composed of white and random walk noises. Units are mm/yr. Scaled circles represent significant instrumental and historical earthquakes. Moment tensor solution of the 2003 Benamaurel Earthquake (Mw $=4.1)$ is also shown. 
Eastern Betic Cordillera constitute the Eastern Betic Shear Zone (Bousquet, 1979; De Larouzière et al., 1988; Silva et al., 1993). In this left-lateral tectonic band, the strike of the active faults grades northwards from NNE-SSW to NE--SW and then to ENE-WSW. Active faults in the Eastern Betic Shear Zone were responsible for major earthquakes, such as the 1829 Torrevieja earthquake $\left(\mathrm{I}=\mathrm{IX}-\mathrm{X}, \mathrm{M}_{\mathrm{ms}}=6.6\right)$ and the 2011 Lorca earthquake ( $=$ VIII, $\mathrm{Mw}=5.1$ ).

To the west of the BsB (Fig. 1), the Central Betic Cordillera is dominated by active ENE-WSW extension (Galindo-Zaldívar et al., 1993; Stich et al., 2006, 2007; Pérez-Peña et al., 2010). This extension has been explained as related to active subduction with rollback (e.g., Gutscher et al., 2002; Galindo-Zaldívar et al., 2015; Gonzalez-Castillo et al., 2015), deep-seated delamination processes (e.g., Fadil et al., 2006; Pérouse et al., 2010; Petit et al., 2015; Baratin et al., 2016; among others) or slab drag (Spakman et al., 2018). The active extension is mainly accommodated by NNW-SSE to WNW-ENE high-angle normal faults (Galindo Zaldivar et al., 2003). Some of these active faults are the seismogenic sources of several of the larger earthquakes that have occurred in the Iberian Peninsula, such as the 1884 Andalusian earthquake ( $\mathrm{I}=$ VIII-IX, $\mathrm{M}_{\mathrm{ms}}=6.5$ ), the 1531 Baza earthquake ( $=$ VIII-IX, $\mathrm{M}_{\mathrm{ms}}=6.0$ ), and the 1956 Purchil earthquake ( $\mathrm{mD}=5.0$ ). In the Central Betic Cordillera, regional geodetic analyses quantified the broad extension to between $\sim 2.1$ and $\sim 3.7 \mathrm{~mm} / \mathrm{yr}$ (Serpelloni et al., 2007; Stich et al., 2007; Pérez-Peña et al., 2010; Ruano and da Silva Fernandes, 2020). Discrepancies in these regional extensional rates are related to the area considered in the studies cited above. Data from the Topo-Iberia project obtained from continuous GPS (CGPS) stations indicate that displacement of the Central and Eastern Betic Cordillera is westward (with a southwestward component) in relation to stable Eurasia (Galindo-Zaldívar et al., 2015; Gonzalez-Castillo et al., 2015). These CGPS data also indicate that displacement significantly increases southwards and westwards (Galindo-Zaldívar et al., 2015; Gonzalez-Castillo et al., 2015). However, the regional scale of these studies hinders the relation of these extensional rates to specific faults.

\section{Active faults of the Baza sub-Basin}

Two major active faults have been described in the BsB: the normal Baza Fault and the strike-slip Galera Fault (Alfaro et al., 2008; García Tortosa et al., 2011; Medina-Cascales et al., 2020) Fig. 2). The largest recorded earthquake in the BsB is the historical 1531 Baza earthquake (I $=$ VIII-IX; $\mathrm{Mw}=6.0$ ). This earthquake, responsible for 310 deaths and the destruction of the city of Baza (Olivera Serrano, 1995), was likely produced by the Baza Fault (Alfaro et al., 2008; Sanz de Galdeano et al., 2012). In the instrumental record, the larger earthquakes are the 1962 Caniles event ( $\mathrm{mbLg}=4.7$, probably related to the Baza Fault) and the 1964 Galera earthquake ( $\mathrm{mbLg}=4.8$, probably related to the Galera Fault). Recently, Castro et al. (2018) postulated a palaeoseismic history of the Baza Fault involving 8 or 9 surface-rupturing events for the last 45 kyr.

The Baza Fault is a $40 \mathrm{~km}$-long normal fault, with a mean strike of N155E and dips ranging between $45^{\circ}$ and $65^{\circ} \mathrm{E}$ (Alfaro et al., 2008; Sanz de Galdeano et al., 2012; Haberland et al., 2017). Faulting initiated in the late Miocene (ca. $8 \mathrm{Ma}$ ), producing a cumulative vertical throw of $\sim 2000 \mathrm{~m}$. The Baza Fault developed a half-graben in the hanging wall (Alfaro et al., 2008; Haberland et al., 2017). At the surface, the Baza Fault consists of a fault array with variable width and a variable number of sub-parallel strands. The Baza Fault can be divided into two main sections (Fig. 2): a narrow N010E-striking north section and a N135E-striking south section that widens southwards. The long-term geological slip rate of the Baza Fault ranges between 0.2 and 0.7 $\mathrm{mm} / \mathrm{yr}$ (Alfaro et al., 2008; García Tortosa et al., 2011; Sanz de Galdeano et al., 2012). Higher slip rates have also been proposed for the Baza Fault (Fernández-Ibáñez et al., 2010). However, these higher values are based on a geomorphological marker that was recently reinterpreted as older (García Tortosa et al., 2011); hence, slip rates should also be reinterpreted as within the abovementioned range.

The Galera Fault is a $25 \mathrm{~km}$-long structure striking N065E. Scarce geological kinematic indicators seem to show that the Galera Fault presents left-lateral kinematics with a minor vertical component (García Tortosa et al., 2011). The only geological quantitative data point to a vertical slip rate ranging between $\sim 0.08$ and $\sim 0.24 \mathrm{~mm} / \mathrm{yr}$ (García Tortosa et al., 2011). For the Galera Fault, the only reported slip rate refers to the minor vertical component of the total displacement. This long-term geological vertical slip rate ranges between 0.1 and 0.2 mm/yr (García Tortosa et al., 2011). The lateral (main) long-term slip rate of the Galera Fault remains unknown.

\section{GPS sites, data processing and velocity field estimation}

\subsection{GPS network and data processing}

In 2008, we built a GPS network that includes six sites (Fig. 2). We located the sites as far as possible of fault traces and on the different blocks of the active faults in the study area. To guarantee the same placement of the GPS antennas in each campaign, we used exposed rocks and self-centring mounting devices. We completed six GPS field campaigns in September 2009, 2010, 2011, 2012, 2014 and 2015. The sites were observed for a continuous 96 -h interval in each campaign. The equipment that we used in the 2009 and 2010 campaigns consisted of Leica Geosystem GX1230 receivers and LEIAX1202 antennas, whereas we observed the 2011, 2012, 2014 and 2015 campaigns using LEICA Geosystem AR10 receivers with LEIAR10 antennas. To process the GPS data, we used GIPSY 6.4 in Precise Point Positioning mode. GIPSY is a GNSS-inferred positioning system and orbit analysis simulation software package developed by the Jet Propulsion Laboratory (JPL) (https://gip sy-oasis.jpl.nasa.gov/). We followed the processing strategy described in Bertiger et al. (2010) with zero-ambiguity resolution and an identical standard procedure for all campaigns (Sánchez-Alzola et al., 2014). This GPS processing included the use of JPL final ephemeris and Pole products in the same IGS08 reference frame and the introduction of the FES2004 ocean tide loading model from Lyard et al. (2006). We also applied hydrostatic and wet components of the zenith tropospheric delay and a 10-degree cut-off angle and the calibration parameters for the antenna phase centre.

\subsection{GPS position time series and velocity field estimation}

We represented the position time series to fit the best trend line for each site of the network. We applied linear regression considering the change in antennas between the 2011 and 2012 campaigns, which produced a shift in the time series. Fig. 3 shows the GPS position time series in horizontal components (north and east) in the IGS08 frame for all of the sites in millimetres. The model applied to the original time series, using weighted least squares, consists of an intercept, a linear trend (site velocity) and an offset to account for an antenna change. The error term in these time series is composed of uncorrelated random errors (white noise) and temporally correlated random errors (coloured noise). The temporal correlation is described by a random-walk process. We have assumed a typical magnitude for this process of $1.0 \mathrm{~mm} / \sqrt{ } \mathrm{yr}$. We are aware that a rigorous statistical analysis and a proper fit to the data are essential to obtain a solid and accurate understanding of crustal deformation analysis. The GPS-derived site rates and uncertainties are shown in Table 1. Fig. 2 shows the absolute velocity field from the position time series in the IGS08 reference frame. A more effective representation of the velocity field was estimated through the residual velocities with respect to stable Eurasia. We computed the residual velocity field considering the ITRF2008 plate motion model (Altamimi et al., 2011) with the Eurasian plate as fixed (Fig. 4). The main issue with the GPS-derived residual velocities used in our interpretation is that they are quite small (sub-mm) but are non-zero at the $95 \%$ confidence level (Table 1). 


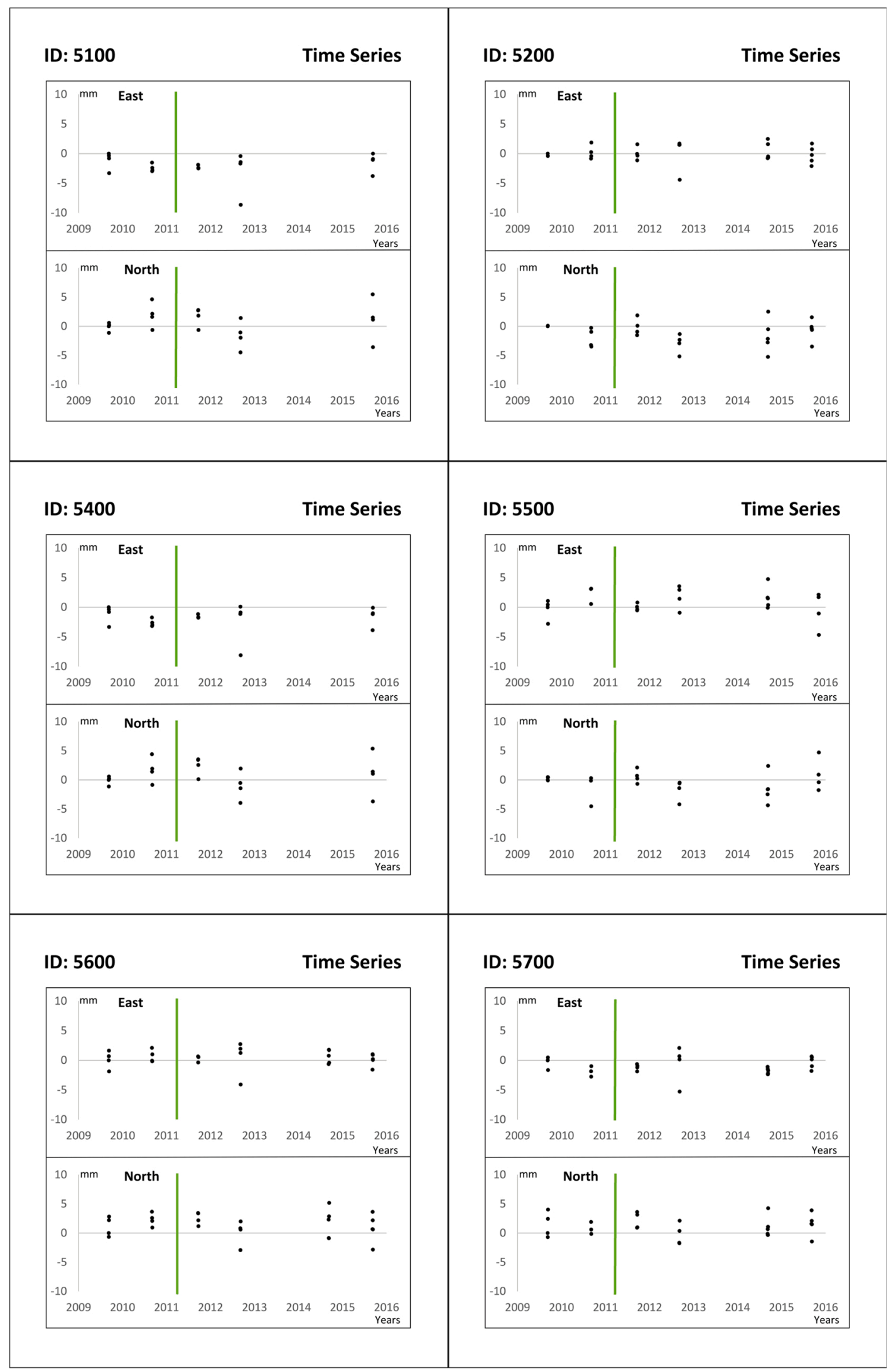

Fig. 3. De-trended position time series in the east and north components for the BsB sites in the IGS08b reference frame. Units are millimetres. Green lines represent antenna change after the 2010 campaign. 
Table 1

East and north absolute velocities estimated for the BsB GPS network. Residual velocities are calculated with respect to a fixed Eurasia as defined by the ITRF2008 plate motion model (Altamimi et al., 2012). Residual velocities projected along the N065E and N115E directions are also shown. All values are given in $\mathrm{mm} / \mathrm{yr}$.

\begin{tabular}{|c|c|c|c|c|c|c|c|c|}
\hline \multirow[b]{2}{*}{ Site } & \multicolumn{4}{|c|}{ Absolute velocities (mm/yr) } & \multicolumn{2}{|c|}{$\begin{array}{l}\text { Residual } \\
\text { velocities (mm/ } \\
\text { yr) }\end{array}$} & \multicolumn{2}{|c|}{$\begin{array}{l}\text { Projected velocities } \\
(\mathrm{mm} / \mathrm{yr})\end{array}$} \\
\hline & VE & $\sigma \mathrm{E}$ & VN & $\sigma \mathrm{N}$ & VE & $\mathrm{VN}$ & N065E & N1155E \\
\hline 5100 & 190 & \pm 0.4 & 16.1 & \pm 0.5 & -0.8 & -0.6 & 0.8 & 0.4 \\
\hline 5200 & 185 & \pm 0.4 & 16.2 & \pm 0.6 & -1.3 & -0.5 & 1.2 & 0.6 \\
\hline 5400 & 191 & \pm 0.5 & 16.3 & \pm 0.6 & -0.7 & -0.4 & 0.7 & 0.3 \\
\hline 5500 & 183 & \pm 0.5 & 16.2 & \pm 0.5 & -1.4 & -0.5 & 1.4 & 0.6 \\
\hline 5600 & 191 & \pm 0.5 & 16.1 & \pm 0.5 & -0.7 & -0.6 & 0.8 & 0.4 \\
\hline 5700 & 185 & \pm 0.4 & 15.8 & \pm 0.4 & -1.2 & -0.8 & 1.3 & 0.6 \\
\hline
\end{tabular}

\section{Fault slip rates}

All of the sites located in the BsB move towards the WSW at different rates with respect to stable Eurasia (Fig. 4), i.e., roughly perpendicular to the convergence direction between the Nubian and Eurasian plates (N323E \pm 1.8 ; Argus et al., 2011). The residual velocity vectors that we obtained (Fig. 4) can be preliminarily grouped into two sets according to their values. i) Vectors set 1 has residual velocities (E component) ranging between $-1.2 \pm 0.5$ and $-1.4 \pm 0.4 \mathrm{~mm} / \mathrm{yr}$; this first set includes sites 5200, 5500, and 5700 (Fig. 4, Table 1). ii) Set 2 includes vectors with velocities ( $\mathrm{E}$ component) ranging between $-0.7 \pm 0.6$ and $-0.8 \pm 0.5$ $\mathrm{mm} / \mathrm{yr}$; this second set comprises sites 5100, 5400, and 5600 (Fig. 4, Table 1). Set 1 includes sites located in the footwall of the Baza Fault and the north block of the Galera Fault. Set 2 includes sites located in the hanging wall of the Baza Fault and the south block of the Galera Fault (Fig. 4).

To discuss these residual velocities in terms of fault slip rates and kinematics, we projected the obtained vectors along the N065E direction, which is sub-perpendicular to the mean strike of the Baza Fault and parallel to the Galera Fault (Fig. 5, Table 1).

\subsection{Baza Fault slip rate}

To interpret the GPS-derived velocities in terms of the Baza Fault slip rate, we first subtract the residual velocities of stations located to the west and east of the Baza Fault along two profiles. The first profile crosscuts the north section of the Baza Fault, as it involves sites 5500 and 5400 (Fig. 5). After this analysis, we obtain a value for the N065E component of the motion of $\mathrm{V}_{\mathrm{N}-\mathrm{N} 065 \mathrm{E}}=0.7 \pm 0.4 \mathrm{~mm} / \mathrm{yr}$ (Fig. 5, Tables 1 and 2). The second profile cross-cuts the south section of the Baza Fault, as it involves sites 5100 and 5200 (Fig. 5). In this case, our analyses yield a velocity of $\mathrm{V}_{\mathrm{S}-\mathrm{N} 065 \mathrm{E}}=0.3 \pm 0.3 \mathrm{~mm} / \mathrm{yr}$ (Fig. 5, Tables 1 and 2).

These values seem to indicate less extension in the south section of the Baza Fault than in the north section. We must be cautious due to the low signal-to-noise ratio observed at the $95 \%$ confidence level, but this lower extension rate in the south section of the Baza fault is consistent with geologic, geomorphologic and geophysical data, as (1) the geomorphic expression of the fault scarp is subtler towards the south (García-Tortosa et al., 2008), (2) the total displacement of recent geologic markers is less in the south section (García Tortosa et al., 2011), and (3) subsurface data also indicate that the total cumulative throw of the Baza Fault is lower in the south section (Alfaro et al., 2008; Haberland et al., 2017). The lower velocity computed along the second profile could also be related to the relative location with respect to the fault tip line. Faults tend to present maximum displacement in their central part that gradually decreases towards the tips (Barnett et al., 1987; Ferill and Morris, 2001, among many others). The second profile (in the south section of the Baza Fault) is located closer to the southern fault tip line than the first profile (in the north section of the Baza Fault) is to the northern tip line (Fig. 5); therefore, a lower velocity is expected along the southern profile.

After the above analysis, we use a simple geometrical calculation to compute the short-term slip rate of the Baza Fault for the first time. For this computation, we use the short-term displacement rates of the N065E components of motion for the north and south sections $\left(\mathrm{V}_{\mathrm{N}-\mathrm{N} 065 \mathrm{E}}=0.7 \pm\right.$ $0.4 \mathrm{~mm} / \mathrm{yr}$ and $\mathrm{V}_{\mathrm{S}-\mathrm{N} 065 \mathrm{E}}=0.3 \pm 0.3 \mathrm{~mm} / \mathrm{yr}$, respectively; Fig. 5 , Tables 1 and 2). In addition, we consider dips of the Baza Fault ranging between $45^{\circ}$ and $60^{\circ}$, according to both surface and subsurface data (Alfaro et al., 2008; Haberland et al., 2017). We obtain a slip rate on the north section ranging between $0.9 \pm 0.4 \mathrm{~mm} / \mathrm{yr}$ (assuming a dip of $45^{\circ}$ ) and $1.3 \pm 0.4 \mathrm{~mm} / \mathrm{yr}$ (assuming a dip of $60^{\circ}$ ) (Table 2). Analogously, for the south section, we obtain slip rates ranging between $0.5 \pm 0.3 \mathrm{~mm} / \mathrm{yr}$ (assuming a dip of $45^{\circ}$ ) and $0.7 \pm 0.3 \mathrm{~mm} / \mathrm{yr}$ (assuming a dip of $60^{\circ}$ ) (Table 2).

\subsection{Galera Fault slip rate}

To analyse the slip rate of the strike-slip Galera Fault we also used the N065E (fault direction) projected component of motion of GPS-derived velocities. In this case, we subtract the residual velocities of the stations located to the north (site 5700) and to the south (site 5600) of the Galera Fault (Fig. 4). After this analysis, we obtain a value of the N065E component of the motion of $\mathrm{V}_{\mathrm{N} 065 \mathrm{E}}=0.5 \pm 0.3 \mathrm{~mm} / \mathrm{yr}$ (Fig. 5, Tables 1 and 2). This value indicates that the Galera Fault presents a sinistral strike-slip component. Once again, these are the first quantitative strikeslip rates attributed to the Galera Fault, as previous geological studies quantified only the vertical component of the fault. In any case, geological vertical slip rates (ranging between 0.1 and $0.2 \mathrm{~mm} / \mathrm{yr}$; García-Tortosa et al., 2008, 2011; Sanz de Galdeano et al., 2012) are significantly lower than our GPS-derived strike-slip rates. Consequently, our data further support the interpretation of the Galera Fault as a strike-slip fault with a minor dip-slip component. Our GPS-derived residual velocities are not accurate enough to analyse the perpendicular-to- strike component of movement (transpression or transtension) of the Galera Fault.

\section{Discussion}

In this section, we discuss the implications of the results obtained from our GPS network for the tectonic setting and seismic hazard assessment of this key geodynamic region of the Betic Cordillera.

\subsection{Reconciling geologic and geodetic fault slip rates}

Our GPS-derived data permit us to establish a short-term slip rate on the Baza Fault ranging between $1.3 \pm 0.4 \mathrm{~mm} / \mathrm{yr}$ (north section, dip $60^{\circ}$ ) and $0.5 \pm 0.3 \mathrm{~mm} / \mathrm{yr}$ (south section, dip $45^{\circ}$ ) (Table 2). Alfaro et al. (2008) and García Tortosa et al. (2011) presented the total cumulative throw for stratigraphic and geomorphic markers. With these total throws and the ages of these markers proposed by the abovementioned authors, the long-term slip rate ranges between $0.2 \mathrm{~mm} / \mathrm{yr}$ (assuming a dip of $60^{\circ}$ ) and $0.7 \mathrm{~mm} / \mathrm{yr}$ (assuming a dip of $45^{\circ}$ ). Despite the high uncertainties of these values, the slip rates that we obtain are within the range of those proposed by Alfaro et al. (2008) and García Tortosa et al. (2011). However, we cannot rule out that the geodetic short-term slip rates are higher than the geologic slip rates, particularly for the north section of the Baza Fault. We postulate that the higher short-term geodetic slip rates that we observe on the Baza Fault are real and not an artefact related to the low signal-to-noise ratio observed at the $95 \%$ confidence level. Discrepancies between slip rates derived from different sources are not uncommon (e.g. Oskin et al., 2008; Cowgill et al., 2009). In fact, a scientific debate continues about whether these discrepancies are related to temporal and/or spatial variations in fault activity or are merely the result of the observational limitations of the measurement techniques. Discrepancies between geodetic and geologic slip rates have 


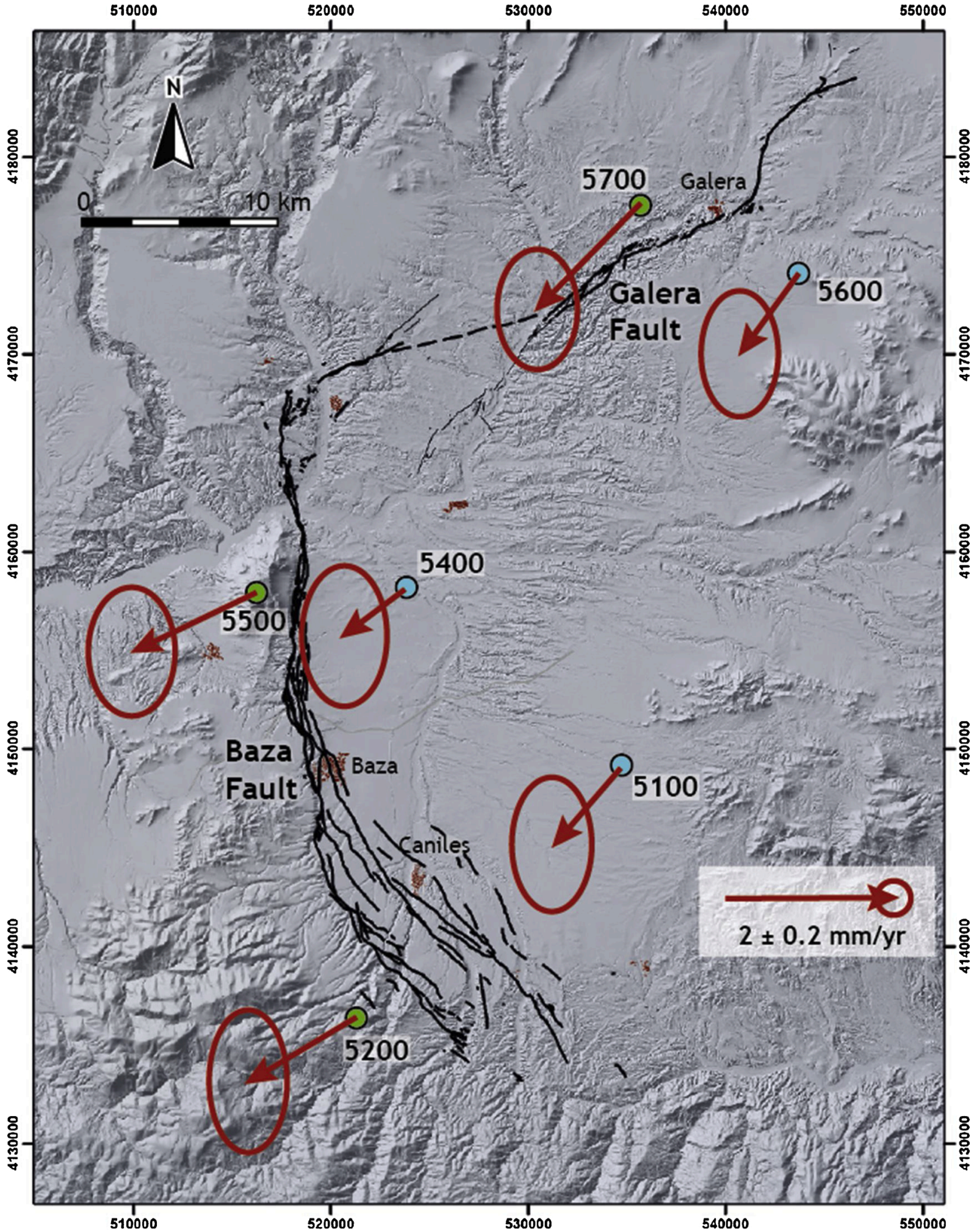

Fig. 4. BsB velocity field with respect to a fixed Eurasia as defined by the ITRF2008 plate motion model and $95 \%$ confidence ellipses. Vectors indicate that all of the sites move sub-perpendicularly to the convergence direction between the Nubian and Eurasian plates (N323E \pm 1.8 ; Argus et al., 2011). Vectors are grouped into two sets according to their values: set 1 includes sites 5200, 5500, and 5700 (green circles); set 2 includes sites 5100, 5400, and 5600 (blue circles).

been explained using a viscoelastic earthquake cycle model (Nur and Mavko, 1974; Savage and Prescott, 1978; Ray and Kaj, 2011; Tong et al., 2014). In this model, steady-state crustal motion is perturbed after a significant earthquake because of a viscoelastic relaxation. That is, the surface strain rate increases after an earthquake and gradually decreases over time. This could be the case for the Baza Fault; however, because of the approximately 500 years elapsed since the last significant earthquake (a magnitude of circa 6 for the 1531 Baza Earthquake), we consider unlikely that postseismic relaxation is still affecting the GPS velocities close to the fault. An alternative interpretation for these 


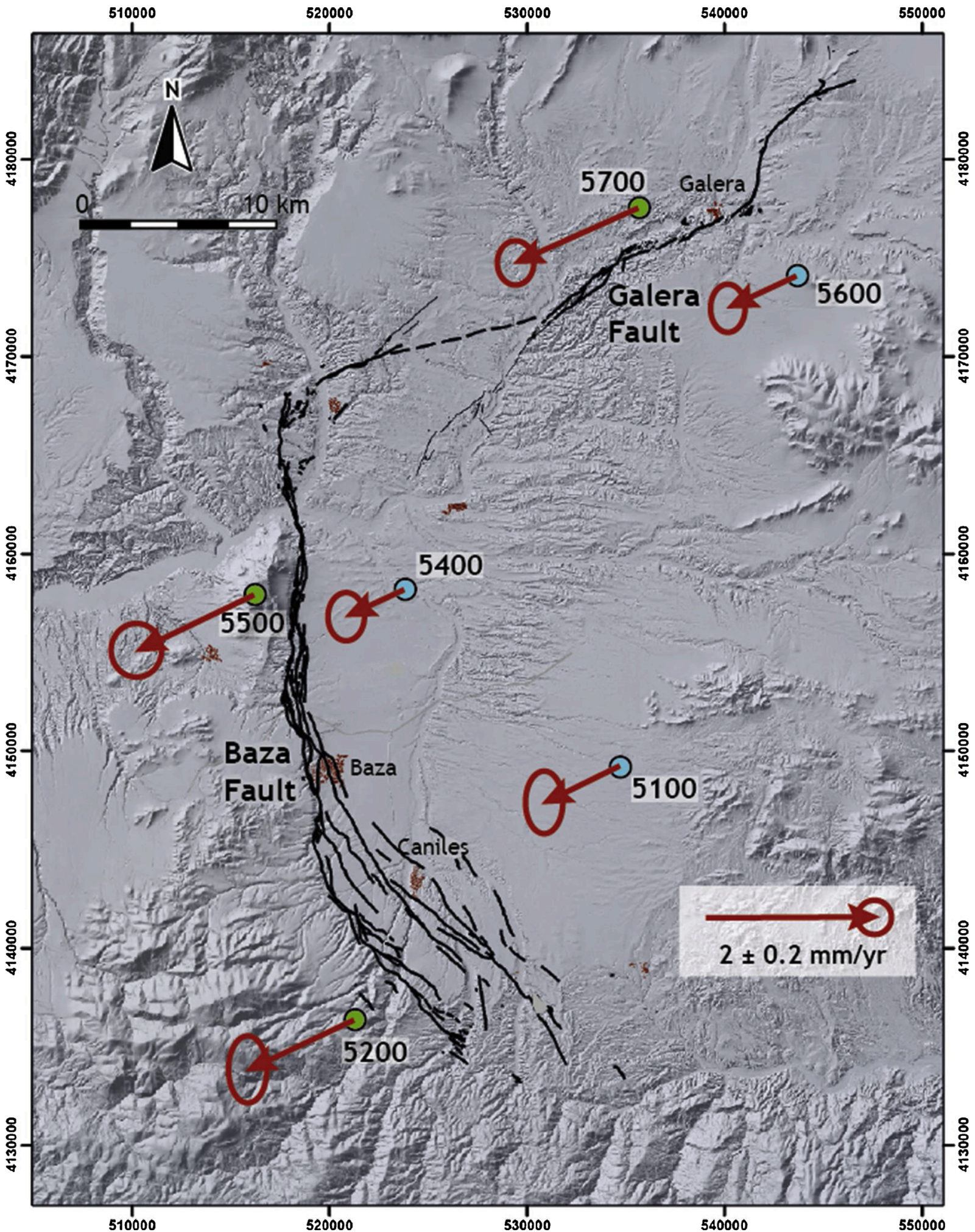

Fig. 5. BsB GPS network residual velocities projected along the N065E direction and $95 \%$ confidence ellipses. Vectors are grouped into two sets according to their values: set 1 includes sites 5200, 5500, and 5700 (green circles); set 2 includes sites 5100, 5400, and 5600 (blue circles).

discrepancies could be related to slip rate variations. In recent years, much evidence seems to indicate that normal fault slip rates vary in both time and space (Nicol et al., 2006; McClymont et al., 2009; Schlagenhauf et al., 2010, among many others). If this is the case for the Baza Fault, our GPS-derived short-term slip rate would indicate that the fault is presently in a period with a displacement rate higher than the mean of the magnitude 6 seismic cycle (i.e., higher than the long-term slip rate). This interpretation would increase the short-term seismic hazard of the region assuming that higher-than-average slip rates are more likely to trigger smaller magnitude events, e.g., in the range of Mw 5, which could also cause much damage to local populations. 
Table 2

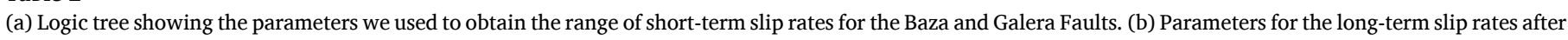
Alfaro et al. (2008) and García Tortosa et al. (2011) are also shown. (c) Chart with both short-term and long-term slip rates for the Baza Fault.

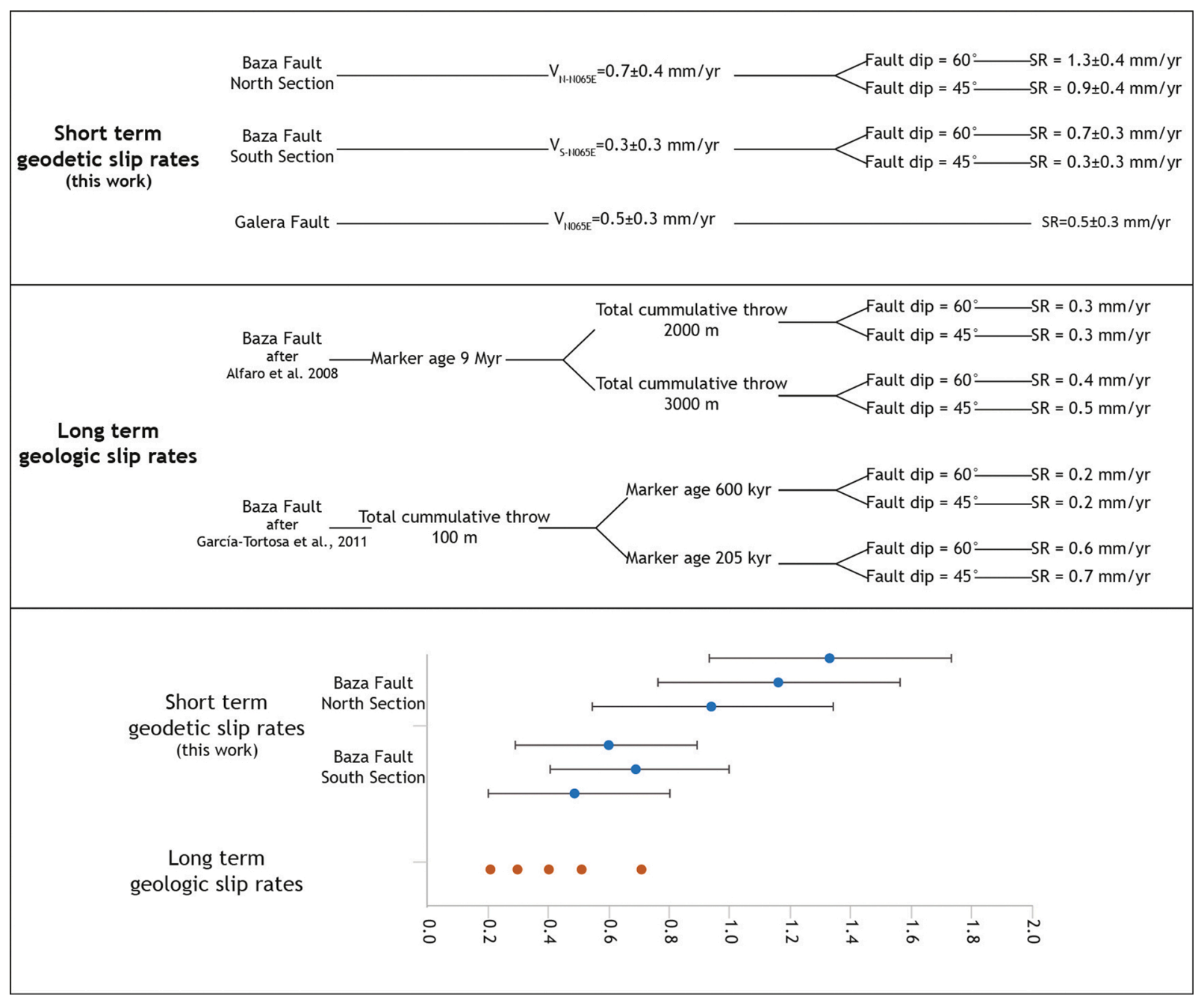

\subsection{Displacement transfer between the Baza and Galera Faults}

The Baza and Galera Faults constitute an active fault system in the BsB (Fig. 2). The interaction of synchronously active faults implies a transfer of displacement between them (e.g., Dahlstrom, 1969; Walsh and Watterson, 1991). Moreover, in active fault systems where different types of faults coexist, kinematic coherence is expected; that is, the displacement rates of the interacting faults should be interdependent. Analyses of kinematic coherence within fault systems are usually approached by applying field data to elucidate fault attitudes, slip directions and displacement rates (Mouslopoulou et al., 2006 and 2008; Nicol et al., 2010). In the BsB, our GPS data provide slip rates that permit us to analyse how displacement is transferred between the normal Baza Fault and the strike-slip Galera Fault, to elucidate whether the fault system is kinematically coherent.

As previously mentioned, the residual velocity vectors that we obtained can be grouped into two sets (Fig. 4, Table 1): i) set 1 comprising sites 5200, 5500, and 5700 with higher residual velocities (E component between $-1.2 \pm 0.5$ and $-1.4 \pm 0.4 \mathrm{~mm} / \mathrm{yr}$ ) and ii) set 2 including sites 5100,5400 , and 5600 with lower residual velocities (E component ranging between $-0.7 \pm 0.6$ and $-0.8 \pm 0.5 \mathrm{~mm} / \mathrm{yr}$ ). Set 1 includes all the sites located in the footwall of the Baza Fault and in the north block of the Galera Fault. Set 2 includes the rest of the sites, i.e., all the sites located in the hanging wall of the Baza Fault and in the south block of the Galera Fault (Fig. 4). According to these observations, and using caution because of the low signal-to-noise ratio observed at the $95 \%$ confidence level, we propose that the BsB could be structured into two main tectonic blocks (Fig. 6): i) a southeastern block made up of the hanging wall of the Baza Fault and the south block of the Galera Fault and ii) a northwestern block made up of the footwall of the Baza fault and the north block of the Galera Fault. To test the displacement transfer and kinematic coherence of the BsB fault system, we use our GPS data to analyse the slip azimuths and displacement rates of the Baza and Galera Faults. A requirement in synchronously active fault systems involving only two tectonic blocks is that the slip directions of all faults within the system must be sub-parallel (Mouslopoulou et al., 2006). In the BsB fault system, this slip parallelism is confirmed by our residual velocity vectors, which present a sub-parallel WSW azimuth with respect to stable Eurasia (Fig. 4). Global data compiled by Mouslopoulou et al. (2006) indicate that in kinematically coherent fault systems involving normal and strike-slip faults, extension and strike-slip rates are equal (Fig. 7). Our GPS-derived vectors seem to indicate that this is also the case in the BsB fault system, as the extension rates on the normal Baza Fault are within the range of the strike-slip rates on the Galera Fault $\left(\mathrm{V}_{\mathrm{N}-\mathrm{N} 065 \mathrm{E}}=\right.$ $0.7 \pm 0.4 \mathrm{~mm} / \mathrm{yr}$ and $\mathrm{V}_{\mathrm{N} 065 \mathrm{E}}=0.5 \pm 0.3 \mathrm{~mm} / \mathrm{yr}$, respectively; Fig. 7 and Table 2).

\subsection{Regional tectonic significance of the Baza and Galera Faults}

Our GPS-derived data also permit us to discuss the regional tectonic 


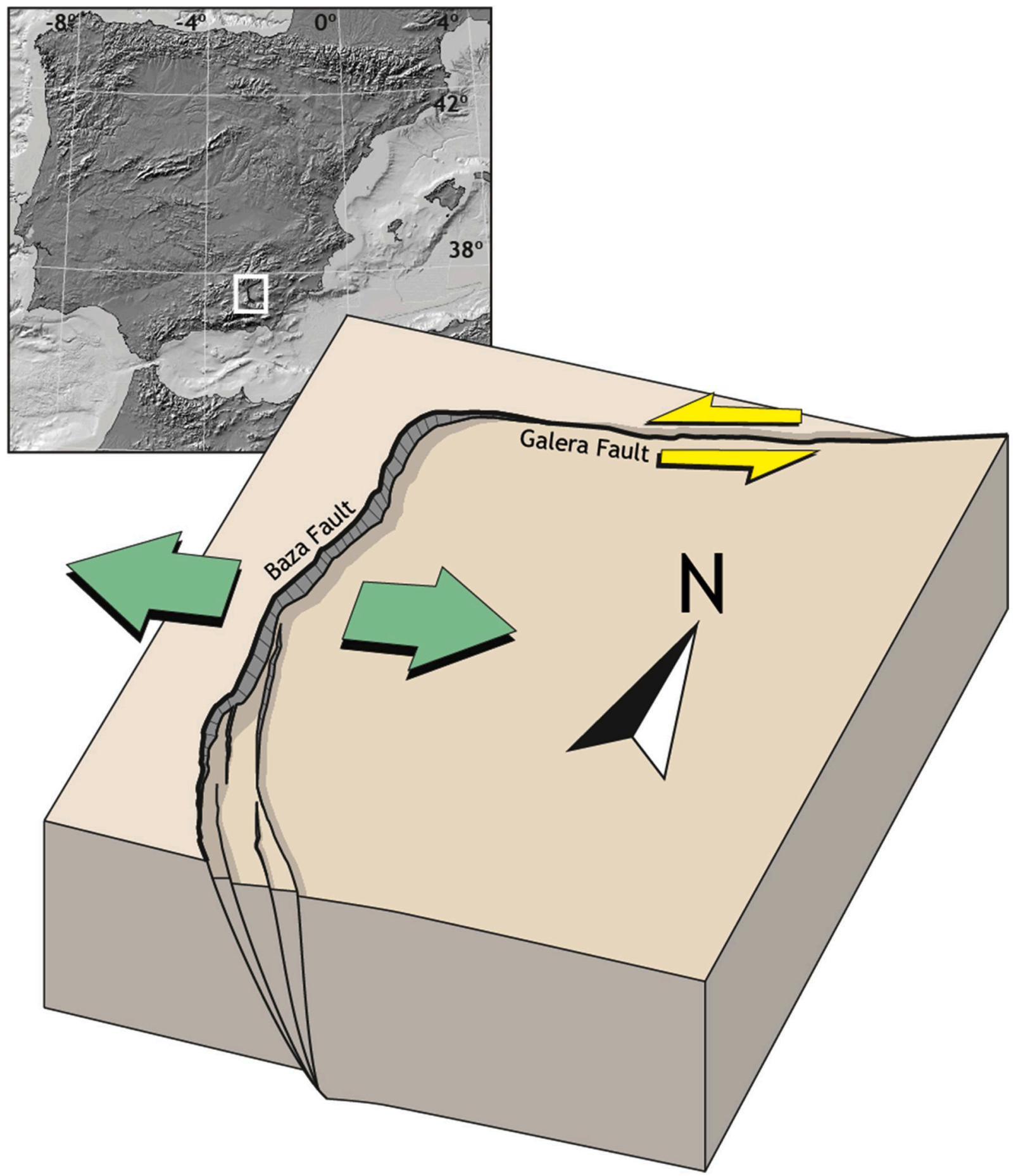

Fig. 6. BsB tectonic sketch showing the kinematic coupling between the Baza and Galera Faults (see white square in inset for location).

significance of the Baza and Galera Faults. Sites 5200, 5500, and 5700 (vectors set 1) moves towards the WSW direction faster than sites 5100 , 5400 , and 5600, (vectors set 2) (Fig. 4), which is in good agreement with the normal kinematics of the Baza Fault and the regional extension of the Central Betic Cordillera. Our data also seem to indicate that no extension occurs east of the Baza Fault. In fact, no major active normal faults have been described in the Eastern Betic Cordillera (García-Mayordomo et al., 2012; Sanz de Galdeano et al., 2020). Consequently, we postulate that the Baza Fault represents the easternmost limit of the regional extension; hence, the BsB is the transition zone between the two present major tectonic domains of the Betic Cordillera (Fig. 6).

Regional geodetic analyses have quantified the broad ENE-WSW extension in the Central Betic Cordillera to between $\sim 2.1$ and $\sim 3.7$ mm/yr (Serpelloni et al., 2007; Stich et al., 2007; Pérez-Peña et al., 2010). Our data indicate that the N065E component of motion of the Baza Fault ranges between $0.9 \pm 0.4$ and $1.3 \pm 0.4 \mathrm{~mm} / \mathrm{yr}$. This implies that the Baza Fault accommodates approximately one-third of the total regional extension, underlining the seismogenic potential of this active structure. Moreover, recent CGPS data from the Topo-Iberia network in the Central Betic Cordillera (Galindo-Zaldívar et al., 2015) indicate that the regional extension in the area located east of the Sierra Nevada is approximately $0.8 \pm 0.4 \mathrm{~mm} / \mathrm{yr}$ (Fig. 1). Consequently, the Baza Fault accommodates almost all of the extension in this area. 


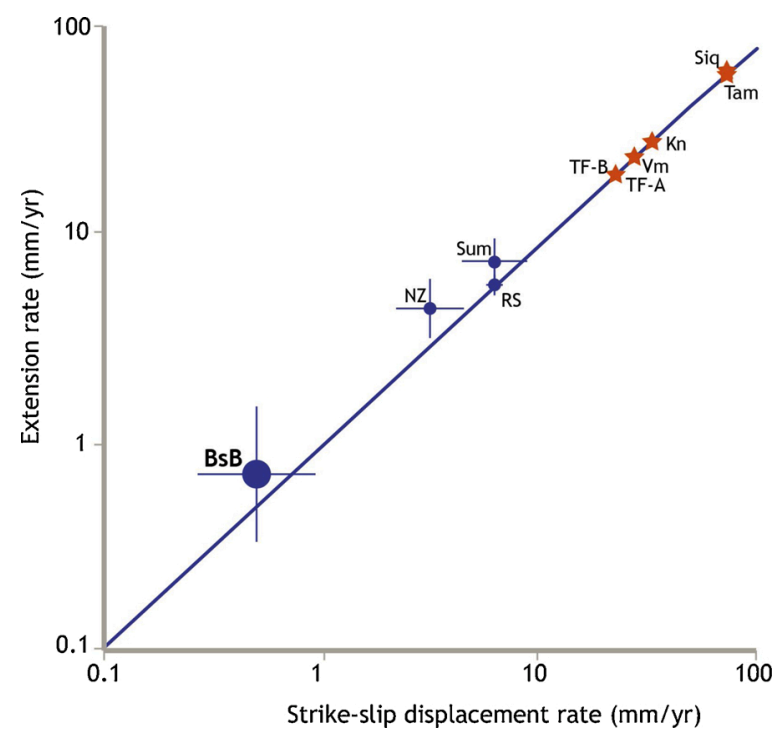

Fig. 7. Strike-slip vs. extension rate log plot for the following fault systems: Taupo rift-North Island Fault System in New Zealand (NZ), Red Sea Rift-Dead Sea Fault (RS), Sumatra Fault-Sunda Strait Rift (Sum), Transform Faults A and $\mathrm{B}$ in the FAMOUS area of the Mid-Atlantic Ridge (TF-A and TF-B), Vema Fracture Zone of the Mid-Atlantic Ridge (Vm), Kane Fracture Zone of the MidAtlantic Ridge (Kn), Siqueiros Fracture Zone of the East Pacific Rise (Siq), and Tamayo Fracture Zone of the East Pacific Rise (Tam). Our GPS-derived displacement rates for the BsB are also plotted. The blue line represents equal strike-slip and extension rates. Modified from Mouslopoulou et al. (2006).

\subsection{Implications for seismic hazard assessment}

Our GPS data permit us to quantify short-term slip rates on the Baza and Galera Faults for the first time. These slip rates will facilitate future seismic hazard assessment studies in this region. However, our data also permit us to propose a local tectonic model for the BsB with implications for the seismic potential of this area. As we have already mentioned, the active extension in the Central Betic Cordillera is mainly accommodated by NW-SE normal faults. This deformation is heterogeneously distributed, as areas of active extension are physically separated but kinematically coupled through WSW-ENE strike-slip transfer fault zones (Martínez-Martínez et al., 2006; Pedrera et al., 2006; Galindo-Zaldivar et al., 2013). As discussed above, we interpret the Baza Fault as the main active structure in the BsB accommodating the regional ENE-WSW extension. Moreover, our GPS data also indicate that the Baza and Galera Faults are kinematically linked. In addition, no major normal faults have been described east of the Galera Fault. Consequently, we postulate that the Galera Fault is a transfer fault bounding the margin of an extended area (Fig. 6).

The tectonic model discussed above also has implications for the seismic potential of the BsB. Complex ruptures involving multiple faults with a wide range of orientations, senses of movement, slip rates, recurrence intervals and even crossing tectonic domain boundaries have been documented for several historical earthquakes around the world (Matsuda, 1974; Wallace, 1984; Beanland et al., 1989; Sieh et al., 1993; Kurushin et al., 1997; Beavan et al., 2012; Schwartz et al., 2012). The factors contributing to these complex ruptures are being analysed after several events occurred in the last few years, such as the El Mayor-Cucapah 2010 earthquake (Fletcher et al., 2014), the Sumatra 2012 earthquake (Meng et al., 2012), and the Kaikoura 2016 earthquake (Litchfield et al., 2018). Likely factors contributing to complex ruptures include physical linkages between faults and inherited geological structures, among others (Litchfield et al., 2018). Our interpretation of the GPS data indicates that the Baza and Galera Faults are kinematically coupled, pointing to a likely physical linkage between the two faults. Consequently, we postulate that a complex rupture involving both the
Baza and Galera Faults should be considered in future seismic hazard assessment studies.

\section{Conclusions}

Our results are the first GPS-derived data obtained from the BsB, a key tectonic area in the Betic Cordillera prone to significant earthquakes. Despite the low signal-to-noise ratios of our residual velocities, which are related to the relatively slow (sub-millimetric) strain rate in this region, the results that we obtain are in good agreement with geological observations and regional geodetic data.

Our local study quantifies for the first time the short-term slip rates on active faults in this area. We obtain slip rates for the Baza Fault ranging between $0.3 \pm 0.3 \mathrm{~mm} / \mathrm{yr}$ and $1.3 \pm 0.4 \mathrm{~mm} / \mathrm{yr}$. These values seem to be higher than previously reported long-term geological slip rates, indicating that the fault could be presently in a period with a displacement rate higher than the mean of the magnitude 6 seismic cycle. Our analysis provides a slip rate for the lateral (main) component of the Galera Fault $(0.5 \pm 0.3 \mathrm{~mm} / \mathrm{yr})$ for the first time. Our GPS study also indicates that the Baza Fault accommodates one-third of the regional extension of the Central Betic Cordillera and that this structure represents the easternmost active normal fault in the region.

These slip rates will be the basis that will facilitate future seismic hazard assessment studies in this region. In addition, the residual velocities that we obtain seem to indicate that the Baza and Galera Faults are kinematically coherent and that the BsB is structured in two main tectonic blocks with no significant internal deformation. The southeastern block comprises the hanging wall of the Baza Fault and the south block of the Galera Fault, and the northwestern block comprises the footwall of the Baza Fault and the north block of the Galera Fault. This interpretation would also imply that the Baza and Galera Faults are kinematically coupled and physically linked and that a potential complex rupture involving both faults should be considered in seismic hazard assessment studies.

\section{Author statement}

The authors declare that the work described in this manuscript has not been published previously, that it is not under consideration for publication elsewhere, that its publication is approved by all authors and tacitly or explicitly by the responsible authorities where the work was carried out, and that, if accepted, it will not be published elsewhere in the same form, in English or in any other language, including electronically without the written consent of the copyright-holder.

\section{Declaration of Competing Interest}

The authors declare that they have no known competing financial interests or personal relationships that could have appeared to influence the work reported in this paper.

\section{Acknowledgements}

We acknowledge the comments of Editor Prof. Irina M. Artemieva and two anonymous reviewers, which significantly improved the quality of this paper. This research was funded by the Spanish Ministry of Science, Innovation and University (Research Projects: RTI2018-100737-BI00 and CGL2016-80687-R), the University of Alicante (Research Project: VIGROB053), the University of Jaén (PAIUJA 2019-2020 and Programa Operativo FEDER Andalucía 2014-2020 - call made by UJA 2018), the University of Granada (B-RNM-301-UGR18) and the Junta de Andalucía regional government (RNM148, RNM282, and RNM370 and P18-RT-3275 research groups). We thank all observers who collected the data of survey-mode GPS measurements. 


\section{References}

Alfaro, P., Delgado, J., Sanz de Galdeano, C., Galindo- Zaldívar, J., García-Tortosa, F.J., López-Garrido, A.C., López-Casado, C., Marín-Lechado, A., Gil, A., Borque, M.J., 2008. The Baza Fault: a major active extensional fault in the central Betic Cordillera (south Spain). Int. J. Earth Sci. 97, 1353-1365.

Altamimi, Z., Collilieux, X., Métivier, L., 2011. ITRF2008: an improved solution of the international terrestrial reference frame. J. Geod. 858, 457-473. https://doi.org/ 10.1007/s00190-011-0444-4.

Argus, D.F., Gordon, R.G., DeMets, C., 2011. Geologically current motion of 56 plates relative to the no-net-rotation reference frame. Geochem. Geophys. Geosystems 12, Q11001. https://doi.org/10.1029/2011GC003751.

Baratin, L.M., Mazzotti, S., Vernant, J.C.P., Tahayt, A., Mourabit, T., 2016. Incipient mantle delamination, active tectonics and crustal thickening in Northern Morocco: Insights from gravity data and numerical modeling. Earth Planet. Sci. Lett. 454, 113-120. https://doi.org/10.1016/j.epsl.2016.08.041.

Barnett, J.A.M., Mortimer, J., Rippon, J.H., Walsh, J.J., Watterson, J., 1987. Displacement geometry in the volume containing a single normal fault. Am. Assoc. Pet. Geol. Bull. 71, 925-937.

Beanland, S., Berryman, K.R., Blick, G.H., 1989. Geological investigations of the 1987 Edgecumbe earthquake, New Zealand, new zeal. J. Geol. Geophys. 32, 73-91.

Beavan, J., Motagh, M., Fielding, E.J., Donnely, N., Collett, D., 2012. Fault slip models of the 2010-2011 Canterbury, New Zealand, earthquakes from geodetic data and observations of postseismic ground deformation, New Zeal. J. Geol. Geophys. 55, 207-221.

Borque, M., Sanchez-Alzola, A., Martin-Rojas, I., Alfaro, P., Molina, S., Rosa-Cintas, S., Rodríguez-Caderot, G., Lacy, C., García-Armenteros, J., Avilés, M., Herrera-Olmo, A. García-Tortosa, F., Estévez, A., Gil, A.J., 2019. How much nubia-eurasia convergence is accommodated by the NE end of the eastern betic shear zone (SE Spain)? Constraints from GPS velocities. Tectonics 38, 1824-1839. https://doi.org/10.1029/ 2018TC004970.

Bousquet, J.C., 1979. Quaternary strike-slip faults in Southeastern Spain. Tectonophysics 52, 277-286.

Castro, J., Martin-Rojas, I., Medina-Cascales, I., García-Tortosa, F.J., Alfaro, P., InsuaArévalo, J.M., 2018. Active faulting in the central betic Cordillera (Spain): palaeoseismological constraint of the surface-rupturing history of the Baza Fault (central betic Cordillera, Iberian peninsula). Tectonophysics 736, 15-30. https://doi. org/10.1016/j.tecto.2018.04.010.

Colomina, I., Fleta, J., Giménez, J., Goula, X., Masana, E., Ortiz, M.A., Santanach, P., Soro, M., Suriñach, E., Talaya, J., Térmens, A., 1998. The CuaTeNeo(*) GPS network to quantify horizontal movements in the southeastern part of the iberian peninsula. $1^{\text {a }}$ Assembleia Luso Española De Geodesia E Geofísica. Asamblea Hispano Portuguesa De Geodesia Y Geofísica. SIM1-01, 1 / 6.

Coppier, G., Griveaud, P., de Larouziere, F.D., Montenat, C., Ott d'Estevou, P., 1989. Example of neogene tectonic indentation in the eastern betic cordilleras: the arc of águilas (southeastern Spain). Geodin. Acta 3 (1), 37-51.

Cornell, C.A., 1968. Engineering seismic risk analysis. Bull. Seismol. Soc. Am. 58 (5), $1583-1606$.

Cowgill, E.R., Gold, D., Chen, X.H., Wang, X.F., Arrowsmith, J.R., Southon, J., 2009. Low Quaternary slip rate reconciles geodetic and geologic rates along the Altyn Tagh fault, northwestern Tibet. Geology 37, 647-650.

Dahlstrom, C.D.A., 1969. Balanced cross sections. Can. J. Earth Sci. 6, 743-757.

De Larouzière, F., Bolze, J.J., Larouzière De, F.D., Montenat, C., Ott d'Estevou, P., 1988. The Betic segment of the lithospheric trans-Alboran shear zone during the late Miocene. Tectonophysics 152, 41-52.

Echeverria, A., Khazaradze, G., Asensio, E., Gárate, J., Martín-Dávila, J., Surinãch, E., 2013. Crustal deformation in eastern Betics from CuaTeNeo GPS network. Tectonophysics 608, 600-612.

Echeverria, A., Khazaradze, G., Asensio, E., Masana, E., 2015. Geodetic evidence for continuing tectonic activity of the Carboneras Fault (SE Spain). Tectonophysics 663, 302-309.

Fadil, A., Vernant, P., McClusky, S., Reilinger, R., Gomez, F., Ben Sari, D., Mourabit, T., Feigl, K., Barazangi, M., 2006. Active tectonics of the western Mediterranean: geodetic evidence for rollback of a delaminated subcontinental lithospheric slab beneath the Rif Mountains, Morocco. Geology 34 (7), 529-532 doi: https://doi.org/ 10.1130 .

Faure Walker, J.P., Roberts, G.P., Sammonds, P.R., Cowie, P.A., 2010. Comparison of earthquake strains over 102 to 104 year timescales: insights into variability in the seismic cycle in central Apennines, Italy. J. Geophys. Res. 115, B10418 https://doi. org $/ 10.1029 / 2009 J B 006462$.

Ferill, D.A., Morris, A.P., 2001. Displacement gradient and deformation in normal fault systems. J. Struct. Geol. 23, 619-638.

Fletcher, J.M., Teran, O.J., Rockwell, T.K., Oskin, M.E., Hudnut, K.W., Mueller, K.J., Spelz, R.M., Akciz, S.O., Masana, E., Faneros, G., et al., 2014. Assembly of a large earthquake from a complex fault system: surface rupture kinematics of the 4 April 2010 El Mayor-cucapah (Mexico) mw 7.2 earthquake. Geosphere 10, 797-827.

Galindo Zaldívar, J., Gil, A.J., Borque, M.J., González-Lodeiro, F., Jabaloy, A., MarínLechado, C., Ruano, P., Sanz de Galdeano, C., 2003. Active faulting in the internal zones of the central Betic Cordilleras (SE, Spain). J. Geodyn. 36, 239-250.

Galindo-Zaldivar, J., Borque, M., Pedrera, A., Marín-Lechado, C., Gil, A.J., LópezGarrido, A.C., 2013. Deformation behaviour of the low-rate active Balanegra Fault Zone from high-precision levelling (Betic Cordillera, SE Spain). J. Geodyn. 71, 43-51. https://doi.org/10.1016/j.jog.2013.07.003.

Galindo-Zaldívar, J., González-Lodeiro, F., Jabaloy, A., 1993. Stress and paleostress in the Betic-Rif Cordilleras (Miocene to present-day). Tectonophysics 227, 105-126.
Galindo-Zaldívar, J., Gil, A.J., Sanz de Galdeano, C., Lacy, M.C., García-Armenteros, J.A., Ruano, P., Ruiz, A.M., Martínez-Martos, M., Alfaro, P., 2015. Active shallow extensión in central and Eastern Betic Cordillera from CGPS data. Tectonophysics 663, 290-301.

García Tortosa, F.J., Alfaro, P., Galindo Zaldívar, J., Sanz de Galdeano, C., 2011. Glacis geometry as a geomorphic marker of recent tectonics: the Guadix-Baza Basin (South Spain). Geomorphology 125, 517-529. https://doi.org/10.1016/j. geomorph.2010.10.021.

García-Mayordomo, J., Insua-Arévalo, J.M., Martínez-Díaz, J.J., Jiménez-Díaz, A. Martín-Banda, R., Martín-Alfageme, S., Álvarez-Gómez, J.A., Rodríguez-Peces, M., Pérez-López, R., Rodríguez-Pascua, M.A., Masana, E., Perea, H., Martín-González, F., Giner-Robles, J., Nemser, E.S., Cabral, J., the QAFI Compilers Working Group, 2012. The quaternary faults database of iberia (QAFI v.2.0). J. Iber. Geol. 38 (1), 285-302.

García-Tortosa, F.J., Alfaro, P., Galindo Zaldívar, J., Gibert, L., López Garrido, A.C., Sanz de Galdeano, C., Ureña, M., 2008. Geomorphologic evidence of the active Baza Fault (Betic Cordillera, south Spain). Geomorphology 97, 374-391.

Gil, A.J., Rodríguez-Caderot, G., Lacy, C., Ruiz, A., Sanz, C., Alfaro, P., 2002. Establishment of a non-permanent GPS network to monitor the deformation in Granada Basin (Betic Cordillera, Southern Spain). Stud. Geophys. Geod. 46, 395-410.

Gil, A.J., Galindo-Zaldivar, J., Sanz de Galdeano, C., Borque, M., Sanchez-Alzola, A., Martinez-Martos, M., Alfaro, P., 2017. The Padul normal fault activity constrained by GPS data: brittle extension orthogonal to folding in the central Betic Cordillera. Tectonophysics 712. https://doi.org/10.1016/j.tecto.2017.05.008.

Giménez, J., 1998. Quantificació De Les Deformacions Verticals Recents a l'Est De La Península Ibèrica a Partir d'anivellaments Topogràfics De Precisió. Monografies Tècniques de l'Institut Cartogràfic de Catalunya, p. 8 (in Catalan).

Giménez, J., Borque, M., Gil, A.J., Alfaro, P., Estévez, A., Surinach, E., 2009. Comparison of long-term and short-term uplift rates along an active blind reverse fault zone (Bajo Segura, Se Spain). Stud. Geophys. Geod. 53, 81-98. https://doi.org/10.1007/ s11200-009-0005-y.

Gonzalez-Castillo, L., Galindo-Zaldivar, J., Lacy, M.C., Borque, M., Martínez-Moreno, F., García-Armenteros, J., Gil, A.J., 2015. Active rollback in the Gibraltar arc: evidences from CGPS data in the Western Betic Cordillera. Tectonophysics 663. https://doi. org/10.1016/j.tecto.2015.03.010.

Gutscher, M.A., Malod, J., Rehault, J.P., Contrucci, I., Klingelhoefer, F., MendesVictor, L., Spakman, W., 2002. Evidence for active subduction beneath Gibraltar. Geology 30 (12), 1071-1074. https://doi.org/10.1130/0091-7613(2002) $030<1071$ :EFASBG > 2.0.CO;2.

Haberland, C., Giber, L., José Jurado, M., Stiller, M., Baumann-Wilke, M., Scott, G., Mertz, D.F., 2017. Architecture and tectono-stratigraphic evolution of the intramontane Baza Basin (Bétics, SE-Spain): constraints from seismic imaging. Tectonophysics 709, 69-84. https://doi.org/10.1016/j.tecto.2017.03.022.

Hreinsdóttir, S., Freymueller, J.T., Bürgmann, R., Mitchell, J., 2006. Coseismic deformation of the 2002 Denali fault earthquake: insights from GPS measurements. J. Geophys. Res. 111.

Kouba, J., 2005. A possible detection of the 26 December 2004 great Sumatra-Andaman Islands earthquake with solution products of the international GNSS Service. Stud. Geophys. Geod. 49, 463-483.

Koulali, A., Ouazar, D., Tahayt, A., King, R.W., Vernant, P., Reilinger, R.E., McClusky, S., Mourabit, T., Davila, J.M., Amraoui, N., 2011. New GPS constraints on active deformation along the Africa-Iberia plate boundary. Earth Planet. Sci. Lett. 308, 211-217.

Kurushin, R.A., Bayasgalan, A., Ölziybat, M., Enkhtuvshin, B., Molnar, P., Bayarsayhan, C., Hudnut, K.W., Lin, J., 1997. The surface rupture of the 1957 GobiAltay, Mongolia, earthquake. Geol. Soc. Am. Spec. Pap. 320, 143 pp.

Larson, K.M., Lowry, A.R., Kostoglodov, V., Hutton, W., Sánchez, O., Hudnut, K., Suárez, G., 2004. Crustal deformation measurements in Guerrero, Mexico. J. Geophys. Res. 109, 1-19.

Litchfield, N.J., Villamor, P., Van Dissen, R.J., Nicol, A., Barnes, P.M., Barrell, D.J.A., Pettinga, J.R., Langridge, R.M., Little, T.A., Mountjoy, J.J., Ries, W.F., Rowland, J., Fenton, C., Stirling, M.W., Kearse, J., Berryman, K.R., Cochran, U.A., Clark, K.J., Hemphill-Haley, M., Khajavi, N., Jones, K.E., Archibald, G., Upton, P., Asher, C., Benson, A., Cox, S.C., Gasston, C., Hale, D., Hall, B., Hatem, A.E., Heron, D.W., Howarth, J., Kane, T.J., Lamarche, G., Lawson, S., Lukovic, B., McColl, S.T., Madugo, C., Manousakis, J., Noble, D., Pedley, K., Sauer, K., Stahl, T., Strong, D.T., Townsend, D.B., Toy, V., Williams, J., Woelz, S., Zinke, R., 2018. Surface Rupture of Multiple Crustal Faults in the 2016 M-w 7.8 Kaikoura, New Zealand, Earthquake. Bull. Seismol. Soc. Am. 108 (3B), 1496-1520. https://doi.org/10.1785/ 0120170300.

Lyard, F., Lefevre, F., Letellier, T., Francis, O., 2006. Modelling the global ocean tides: modern insights from FES2004. Ocean Dyn. 56 (5), 394-415. https://doi.org/ 10.1007/s10236-006-0086-x.

Marin-Lechado, C., Galindo-Zaldívar, J., Gil, A.J., Borque, M.J., De Lacy, M.C., Pedrera, A., López-Garrido, A.C., Alfaro, P., García-Tortosa, F., Ramos, M.I., Rodríguez-Calderot, G., Rodríguez-Fernández, J., Ruiz-Constán, A., Sanz de Galdeano-Equiza, C., 2010. Leveling profiles and a GPS network to monitor the active folding deformation in the Campo de Dalías (Betic Cordillera, Southeastern Spain). Sensors 10 (4), 3504-3518. https://doi.org/10.3390/s100403504.

Martínez-Martínez, J.M., Booth-Rea, G., Azañón, J.M., Torcal, F., 2006. Active transfer fault zone linking a segmented extensional system (Betics, southern Spain): Insight into heterogeneous extension driven by edge delamination. Tectonophysics 422 , 159-173. https://doi.org/10.1016/j.tecto.2006.06.001.

Matsuda, T., 1974. Surface faults associated with Nobi (Mino-Owari) earthquake of 1891, Japan. Bull. Earthq. Res. Inst. Univ. Tokyo 13, 127-162. 
McClusky, S., Reilinger, R., Mahmoud, S., Ben Sari, D., Tealeb, A., 2003. GPS constraints on Africa (Nubia) and Arabia plate motions. Geophys. J. Int. 155, 126-138.

McClymont, A.F., Villamor, P., Green, A.G., 2009. Fault displacement accumulation and slip rate variability within the Taupo Rift (New Zealand) based on trench and 3-D ground-penetrating radar data. Tectonics 28, TC4005. https://doi.org/10.1029/ 2008 TC002334.

McGuire, R.K., 2007. "Probabilistic seismic hazard analysis: Early history. Earthquake Engng Struct. Dyn. 2008 (37), 329-338.

Medina-Cascales, I., Martin-Rojas, I., García-Tortosa, F., Juan, P., Jose, A., Alfaro, P., 2020. Geometry and kinematics of the Baza Fault (central Betic Cordillera, South Spain): insights into its seismic potential. Geologica Acta 18 (11), 1-25. https://doi. org/10.1344/GeologicaActa2020.18.11.

Meng, L., Ampuero, J.-P., Duputel, Z., Luo, Y., Tsai, V.C., 2012. Earthquake in a maze: compressional rupture branching during the $2012 \mathrm{Mw} 8.6$ Sumatra earthquake. Science 337, 724-726.

Mouslopoulou, V., Nicol, A., Little, T.A., Walsh, J.J., 2006. Displacement transfer between intersecting regional strike-slip and extensional fault systems. J. Struct. Geol. 29, 100-116. https://doi.org/10.1016/j.jsg.2006.08.002.

Mouslopoulou, V., Nicol, A., Walsh, J.J., Beetham, D., Stagpoole, V., 2008. Quaternary temporal stability of a regional strike-slip and rift fault intersection. J. Struct. Geol. 30 (4), 451-463. https://doi.org/10.1016/j.jsg.2007.12.005.

Nicol, A., Walsh, J., Berryman, K., Villamor, P., 2006. Interdependence of fault displacement rates and paleoearthquakes in an active rift. Geology 34, 865-868.

Nicol, A., Walsh, J.J., Villamor, P., Seebeck, H., Berryman, K.R., 2010. Normal fault interactions, paleoearthquakes and growth in an active rift. J. Struct. Geol. 32 (8), 1101-1113. https://doi.org/10.1016/j.jsg.2010.

Nocquet, J.M., 2012. Present-day kinematics of the Mediterranean: a comprehensive overview of GPS results. Tectonophysics 579, 220-242.

Nocquet, J.M., Calais, E., 2003. Cristal velocity field of western Europe from permanent GPS array solutions, 1996-2001. Geophys. J. Int. 154, 72-88.

Nur, A., Mavko, G., 1974. Postseismic viscoelastic rebound. Science 183 (4121), 204-206. https://doi.org/10.1126/science.183.4121.204.

Olivera Serrano, C., 1995. La Actividad Sísmica En El Reino De Granada. Estudio histórico y documentos, Madrid, pp. 1487-1531, 112pp.

Oskin, M., Perg, L., Shelef, E., Strane, M., Gurney, E., Singer, B., Zhang, X., 2008. Elevated shear zone loading rate during an earthquake cluster in eastern California. Geology 36, 507-510.

Palano, M., González, P.J., Fernández, J., 2015. The diffuse plate boundary of Nubia and Iberia in the Western Mediterranean: crustal deformation evidence for viscous coupling and fragmented lithosphere. Earth Planet. Sci. Lett. 430, 439-447.

Pedrera, A., Marín-Lechado, C., Galindo-Zaldívar, J., Rodríguez-Fernández, L.R., RuizConstán, A., 2006. Fault and fold interaction during the development of the neogenequaternary almería-níjar basin (SE betic cordilleras). In: Moratti, G., Chalouan, A. (Eds.), Tectonics of the Western Mediterranean and North Africa., 262. Geological Society, London, Special Publications, pp. 217-230.

Pedrera, A., Galindo-Zaldívar, J., Marín-Lechado, C., García-Tortosa, F.J., Ruano, P., López-Garrido, A.C., Azañón, J.M., Peláez, J.A., Giaconia, F., 2012. Recent and active faults and folds in the central-eastern Internal Zones of the Betic Cordillera. J. Iber. Geol. 38, 191-208.

Pérez-Peña, A., Martín-Dávila, J., Gárate, J., Berrocoso, M., Buforn, E., 2010. Velocity field and tectonic strain in Southern Spain and surrounding areas derived from GPS episodic measurements. J. Geodyn. 49, 232-240.

Pérouse, E., Vernant, P., Chéry, J., Reilinger, R., McClusky, S., 2010. Active surface deformation and sub-lithospheric processes in the western Mediterranean constrained by numerical models. Geology 38 (9), 823-826. https://doi.org/ 10.1130/G30963.1.

Petit, C., Le Pourhiet, L., Scalabrino, B., Corsini, M., Bonnin, M., Romagny, A., 2015. Crustal structure and gravity anomalies beneath the Rif, northern Morocco: implications for the current tectonics of the Alboran region. Geophys. J. Int. 202 (1), 640-652. https://doi.org/10.1093/gji/ggv169.

Ray, Y.C., Kaj, M.J., 2011. Reconciling geologic and geodetic model fault slip rate discrepancies in Southern California: consideration of nonsteady mantle flow and lower crustal fault creep. Geology 39 (July 7), 627-630, 2011; doi:10.1130/ G32120.1;

Ruano, P., da Silva Fernandes, R.M., 2020. The geology of iberia: a geodynamic approach : active processes: seismicity. Act. Faulting Relief : Act. Deformation in the Iberian
Peninsula from Geodetic Techniques 4 (7), 5-10. https://doi.org/10.1007/978-3030-10931-8 4.

Ruiz, A.M., Ferhat, G., Alfaro, P., Sanz de Galdeano, C., Lacy, M.C., RodríguezCaderot, G., Gil, A.J., 2003. Geodetic measurement of crustal deformation onNW-SE faults of the Betic Cordillera, Southern Spain, 1999-2001. J. Geodyn. 35, 259-272.

Sánchez-Alzola, A., Sánchez, C., Giménez, J., Alfaro, P., Gelabert, B., Borque, M., Gil, A., 2014. Crustal velocity and strain rate fields in the Balearic Islands based on continuous GPS time series from the XGAIB network (2010-2013). J. Geodyn. 82, 78-86. https://doi.org/10.1016/j.jog.2014.05.005.

Sanz de Galdeano, C., García-Tortosa, F.J., Peláez, J.A., Alfaro, P., Azañón, J.M., Galindo-Zaldívar, J., López-Casado, C., López-Garrido, A.C., RodríguezFernández, J., Ruano, P., 2012. Main active faults in the Granada and Guadix-Baza Basins (Betic Cordillera). J. Iber. Geol. 38, 209-223. https://doi.org/10.5209/rev JIGE.2012.v38.n1.39215.

Sanz de Galdeano, C., Azañón, J.M., Cabral, J., Ruano, P., Alfaro, P., Canora, C., Ferrater, M., García-Tortosa, F., Mayordomo, J., Gràcia, E., Insua-Arévalo, J.M. Jiménez, A., Lacan, P., Marín-Lechado, C., Martín-Banda, R., Martín-González, F., Martinez-Diaz, J.J., Martin-Rojas, I., Masana, E., Simón, J.L., 2020. The geology of Iberia: a geodynamic approach : active processes: seismicity. Act. Faulting Relief : Act. Faults in Iberia 4 (7), 56-65. https://doi.org/10.1007/978-3-030-10931-8_4.

Savage, J., Prescott, W., 1978. Asthenosphere readjustment and the earthquake cycle. J. Geophys. Res. 83 (B7), 3369-3376. https://doi.org/10.1029/JB083iB07p03369.

Schlagenhauf, A., Gaudemer, Y., Benedetti, L., Manighetti, I., Palumbo, L., Schimmelpfennig, I., Finkel, R., Pou, K., 2010. Using in situ Chlorine-36 cosmonuclide to recover past earthquake histories on limestone normal fault scarps: a reappraisal of methodology and interpretations. Geophys. J. Int. 182, 36-72. https://doi.org/10.1111/j.1365-246X.2010.04622.x.

Schwartz, D.P., Haeussler, P.J., Seitz, G.G., Dawson, T.E., 2012. Why the 2002 Denali fault rupture propagated onto the Totschunda fault: implications for fault branching and seismic hazards. J. Geophys. Res. 117 (B11304) https://doi.org/10.1029/ 2011JB008918.

Serpelloni, E., Vannucci, G., Pondrelli, S., Argnani, A., Casula, G., Anzidei, M., Balde, P., Gasperini, P., 2007. Kinematics of the Western Africa-Eurasia plate boundary from focal mechanisms and GPS data. Geophys. J. Int. 169, 1180-1200.

Sieh, K., Jones, L., Hauksson, E., Hudnut, K., Eberhart-Phillips, D., Heaton, T., Hough, S., Hutton, K., Kanamori, H., Lije, A., et al., 1993. Near-field investigations of the Landers earthquake sequence, April to July 1992. Science 260, 171-176.

Silva, P.G., Goy, J.L., Somoza, L., Zazo, C., Bardaji, T., 1993. Landscape response to strike-slip faulting linked to collisional setting: Quaternary tectonics and basin formation in the Eastern Betics, southeastern Spain. Tectonophysics 224 (4), 289-303.

Smith, K.D., Von Seggern, D., Blewitt, G., Preston, L., Anderson, J.G., Wernicke, B.P., Davis, J.L., 2004. Evidence for deep magma injection beneath lake Tahoe, NevadaCalifornia. Science 305, 1277-1280.

Spakman, W., Chertova, M.V., van den Berg, A., van Hinsbergen, D.J.J., 2018. Puzzling features of western Mediterranean tectonics explained by slab dragging. Nat. Geosci. $11,211-216$.

Stich, D., Serpelloni, E., Mancilla, F., Morales, J., 2006. Kinematics of the Iberia-Maghreb plate contact from seismic moment tensors and GPS observations. Tectonophysics 426, 295-317.

Stich, D., Benito Martín, J., Morales, J., 2007. Deformación sísmica y asísmica en la zona Béticas-Rif-Alborán. Revista de la Sociedad Geológica de España 20, 311-320.

Tong, X., Smith-Konter, B., T.Sandwell, D., 2014. Is there a discrepancybetween geological and geodetic sliprates along the San Andreas FaultSystem? J. Geophys. Res. Solid Earth 119, 2518-2538. https://doi.org/10.1002/2013JB010765.

Vernant, P., Fadil, A., Mourabit, T., Ouazar, D., Koulali, A., Martin-Davila, J., Garate, J., McClusky, S., Reilinger, R., 2010. Geodetic constraints on active tectonics of the Western Mediterranean: implications for the kinematics and dynamics of the NubiaEurasia plate boundary zone. J. Geodyn. 49 (3-4), 123-129. https://doi.org/ 10.1016/j.jog.2009.10.007.

Wallace, R.E., 1984. Fault Scarps Formed During the Earthquakes of October 2 1915, Pleasant Valley, Nevada, and Some Tectonic Implications. U.S. Geol. Surv. Profess.. Paper 1274-A, B.

Walsh, J.J., Watterson, J., 1991. Geometric and kinematic coherence and scale effects in normal fault systems. In: Roberts, A.M., Yielding, G., Freeman, B. (Eds.), The Geometry of Normal Faults. Geological Society of London, Special Publication, pp. 193-203. No. 56. 